\title{
Involution Fisheries: Post-Study Model of National Program in Integrated Movement at Community Fishermen's Village Development Arungkeke, Jeneponto
}

Ferawati Azis

Rabihatun Idris

Andi Agustang

Department of Sociology, Universitas Negeri Makassar JIn. Bonto Langkasa Kampus Gunung Sari Baru

Email: fera_songky@yahoo.co.id, rabihatun_idris@yahoo.com, andiagust63@gmail.com

Doi:10.5901/mjss.2017.v8n1p441

\begin{abstract}
In order to achieve a just and prosperous society, the Government in 2007-2010 to implement the construction of the fishing communities disadvantaged, poor, isolated through the National Integrated Village Development Movement with the aim of promoting economic growth and alleviating poverty and improving the infrastructure improvements. The results showed an indication of the vulnerability and poverty can be clearly perceived by the community of Kampung Nelayan Arungkeke, in spite of the physical facts such as the infrastructure is still feasible, but in terms of the fulfillment of daily life for the family members of fishermen have not experienced a prosperous life. It is due, namely: (1) cultural poverty shows the traditions that are not effectively resulting into a consumerist society, there is no future orientation, and there is a paradigm many children a lot of sustenance resulting in continuously increasing population; (2) structural poverty characterized the colonial practices is the strong influence of capitalism, the gap in the sharing system, as well as the uneven distribution of income: (3) approach to social cultural transformation as the impetus to get out of the condition of involution.
\end{abstract}

Keywords: involution fisheries, socio-cultural transformation

\section{Introduction}

The coastal communities of fishermen Arungkeke including people who are still underdeveloped and is in a marginal position, besides, ignorance by the public outside of the structural characteristics of life, social culture society The fishing village of Arungkeke previously numbered only 24 heads of families, but with the policy program of $2007 \mathrm{~s} / \mathrm{d}$ 2010 the government presents 114 livable housing for fishermen who do not own a home is expected to help reduce poverty in the district Jeneponto.

The programs aimed at boosting economic growth, ensuring ease of public access to various social services, facilitate people develop family income and an increase in infrastructure improvements. The success of Crash Program then Central Government, select Jeneponto as the location of Pilot Project. It is the National Program in Integrated Village Development Movement which aims to increase the independence of the village to bring the pillars of the development of public welfare in the villages by improving the quality of human resources, reduce poverty and unemployment. The program, in addition to providing housing assistance is also providing road infrastructure, education, health, fisheries, water, dock, procurement of school equipment, facilities, or capital support productive economy. Even the fishing village inevitably gets extension and advisory activities of various fields such as fisheries, education, gender, and for empowering the viability of the various elements of the government, including non-governmental organizations, in BAPPEDA (2007).

The program is actually expected to improve the quality of life of the fishermen's welfare, but the people in Kampung Nelayan Arungkeke remain in a state of poverty.

Indications of vulnerability and poverty can be clearly perceived by the community of Kampung Nelayan Arungkeke, in spite of the physical fact of such infrastructure is still feasible. But in terms of the fulfillment of daily life for the family members of fishermen have not experienced a prosperous life. The existences in the number of households (families) were not followed by increments house but stay at home which contains one to three households. The community has a tradition that is ineffective and cultural habits such as resigned to fate, resulting in lack of motivation and 
work ethic as an effort to improve the lives.

Approach famous anthropologist, C. Geertz, who developed the concept of "agricultural involution" (1963), imagine the development of rice cultivation in Java as a situation where farmers are working on plots with an area of improvised and came under pressure from population growth. Geertz concept, "involution" can be interpreted as stagnation or congestion agricultural patterns, indicated by the lack of progress is essential.

Conditions that occur in the community is characterized by the concept of involution. The main characteristic involution according to Geertz (1976) is "grow into", does not evolve and change, so it will spread to the other areas in a system. Such conditions are making the people will be slow to change, or at least if they get more movement is movement in the less brought significant progress. This condition is referred to as the "involution". Darmawan Salman (2002), involution is the evolution of delayed, which changes more slowly than the natural evolution. David Kaplan (2002) involution, or a tendency for culture to plunge and confine himself. Akhmad Solihin (2010) involution a process of change that is virtually unchanged. That is, that the face visible changes, but when examined carefully then there is only the changing face without any change in character.

Based on the thought of Clifford Geertz (1973) on the concept of involution of Agriculture, the conditions in the fishing village communities Arungkeke involution can be described the fishery, which is "backtracking". Patterns of impoverishment in Kampung Nelayan Arungkeke as a pattern of culture and tradition that has definitive form although there is no agreement in the form of a formal yet go hand in hand with the development conditions and population growth in the community. In addition, the social system work that is the power of capital owners appear to dominate the primary doctrine of profit maximization, forming exploitative attitude for investors to fishermen and also to the marine fishery resources so that people experiencing poverty and socioeconomic inequality in the structure of fishing communities. In a historical review agricultural involution in Java in 1963, Geertz, describes a cultural pattern that has a definitive form, which continues to grow more complicated for farmers in particular Java. Javanese social life in general, to survive the reality of increasing population and colonial pressure through a process of internal complexification.

Urgency of research is theoretical contributions in the form of a solution, of course, the transformation of socioculture in fishing communities. The transformation of the socio-culture greatly contribute to poverty reduction, especially for fishing communities of Arungkeke who have earned the maximum target of the government towards the development interest. According to Sodjatmoko (1983) economic development is not merely economic development but a transformation of social and cultural change. The development is a change in perception and attitude towards human life as a whole and not in parts. Therefore, it is necessary transformation (the driving force fundamental changes) sociocultural for fishing communities in particular, and for the sake of development in general.

\section{Research Method}

The study used a qualitative approach, which directly led to the circumstances and perpetrators without reducing elements in it. The qualitative approach was to follow the opinion of Sugiono (2011); Muhadjir (1996); Chourmain (2008), that social reality was seen as something holistic (whole), complex, dynamic, meaningful and interactive relationships. Research conducted at the "Kampung Nelayan Arungkeke" Jeneponto of South Sulawesi province. Resources fishing groups palanra 'and papekang, family fishing, apparatus / village heads, community figure, Society of Social Institutions, business of Koperasi Nelayan, Board Community Learning Center (CLC), the Government of Jeneponto Bappeda, Department of Fisheries, Head and Community Leaders.

The data used in the primary data and secondary data. The primary data obtained directly from informants and secondary data throughout the data in the form of authentic reports, documents and archives of information, research results and other written sources supporting primary data. Data collected observation, documentation, in-depth interviews conducted with the use of the local language, in this way the informants speak according to his own language so that the validity of the data is guaranteed.

\section{Result and Discussion}

\subsection{Social Culture plays a role in creating the conditions involution fishery.}

This study examines how culture creates involution fisheries at Kampung Nelayan Arungkeke community. Wignjosoebroto in Suyanto (2008) also mentions that the cultural poverty of powerlessness caused someone in public life in reality will be more determined and influenced by socio-cultural elements.

Potential biological conceived by sea around the residence settled fishing communities, should be able to be a 
great asset for local fishermen in an effort to improve their lives economically. The facility supported by the abundance of the natural resources that exist in the Arungkeke village and there are various facilities such as TPI (fish market), the port, as well as a wide range of industries from small scale to large drying of the catch. Kampung Nelayan Arungkeke community should be prosperous, but in fact the life of fishing communities still are in disability.

Many cultural poverty refers to the customs and consumption where they live well. One of these cultures living lavishly owned by fishing communities such as those in Kampung Nelayan Arungkeke. Usually these groups at lower income levels (Siswanto 2008).

Some socio-cultural factors play a role in creating the conditions involution fisheries, namely:

1. The existence of a culture of consumption at Kampung Nelayan Arungkeke community. When it gets a lot of income, but they usually spend by buying secondary needs without thinking about current inventory lean season.

2. Conduct ignorant as the cause of low productivity and social inequality. The fishing communities have not thought of the future and has the indifference and resignation to fate.

3. The existence of tradition and of the culture, which is considered ineffective.

The pattern of behavior that has lasted quite a long time is the tradition of the remuneration system or the system returns the giving of time to party or celebration is a must. Since it became social problems if not done in accordance systems prevailing in the community of Kampung Nelayan Arungkeke. In addition to the influence of the caste system, especially the formation of the tradition of aristocratic society (Karaeng) that affect the social life of fishing communities in both the daily activities as well as on the organization of the wedding ceremony, celebration etc.

With the condition of the fishing communities, it is in line with the Chambers in Bagong Suyanto (2013) that the causes of poverty consumptive life. Another cause of poverty because of the pressures of economic necessity that cannot be circumvented the poor people. In fact, they are forced to divert and take advantage of credits obtained precisely for activities that are consumptive activities such as social traditions.

The core of the cultural approach is the willingness to consider change, an attitude that is absolutely associated with individualism and rationalism. One approach is the theory of cultural work ethic, which by Toffler (in Mercy, 1987) commented that: the ethos of which means both character and sentiment of the community - what we might call culture. If we talk about ethics, it is always associated with cultural issues. Culture itself not only includes a pattern of behavior. On the other hand, Kartodirdjo (1993) stated that the ethos it refers to the entire process of "habituation" which produces a pattern or institutionalization of values and manifested as attitude, character and mentality. Furthermore, according to Clifford Geertz (in Kartodirdjo, 1993) defines ethos as a fundamental attitude towards themselves and the world emitted in life. So ethos here is an evaluative aspects that are considered, in this case may be asked whether the work can be regarded as a necessity in life, or as something that is bound to the identity that is sacred.

\subsection{Structure as Determinants of Poverty}

According to Selosoemardjan (1980), structural poverty is the poverty suffered by some segments of society, because the social structure of society so that they cannot opt out of the income sources are actually available to them.

The structure prevailing at Kampung Nelayan Arungkeke community is the creation of patterns that are not balanced between the fishing community and the investor thus creating a structural poverty. Another trait that strengthen structural poverty is a very strong dependency between the poor socio-economic classes on it. Poverty has a striking difference to social inequality. Their pattern of relationships patron client resulting patterns of economic activity that is not balanced in Kampung Nelayan Arungkeke community. In addition, there is a pattern typical strata of society in the Arungkeke village, tradition and culture can affect community life for the people of Kampung Nelayan Arungkeke.

Besides the pressure of population growth continually creating a community process are interconnected and interdependent so that the distribution of an additional provision to the rest of his family is certainly in decline or decadence. Conditions that occur in the study site in the concept of involution there were systems that the change and development of the system. But the proposed changes are changes that lead to a slump-slump in a system, this involution process by Geertz (1976) referred to as the "shared poverty".

Observing the social problems in Kampung Nelayan Arungkeke researchers assumed their structure impoverishment of certain groups. No dogma that rolled up to be awake social strata system as well as a process of omission by not providing assistance either personally though these groups have wealth.

On the concept of involution fishery interaction patterns that occur in fishing communities is their colonial characteristics as conceptualized by Geertz. Geertz concepts: first, a culture of patronage that can bring good luck to a group of investors for the purposes of trade so that a prosperous economy only certain people only. The government's 
policy with relocation and provision of related infrastructure associated with the fishing is actually beneficial for certain parties. Party financiers were easier to distribute the catch of fishermen with the availability of fish market. Secondly, the efforts of certain parties retain workers / fishermen and continue to encourage them to produce to meet market needs. This situation realizing economic structures that are intrinsically unbalanced, which by JH Boeke (1946) called economic dualism. Third, the process of impoverishment in Arungkeke is the result of by-products custom / tradition that has lasted a long time. Fourth, the changes that are declining / setback, it is marked by the increasing number of people in each household so the income is getting squeezed.

\subsection{As the Social Transformation of Power Push involution Condition Fisheries Society towards Improved Living Standards of Kampung Nelayan Arungkeke}

Based on the phenomenon that occurs in the community of Kampung Nelayan Arungkeke undergoing the process of involution, the process of change is only visible on the surface so as to create conditions deterioration. The phenomenon of colonial characteristics that develop among the sites would require theoretical approaches that can bring benefit to the community of Kampung Nelayan Arungkeke. The transformation of cultural values and social can be a theoretical solution in this study.

\subsubsection{Cultural values that guide the public to act in dealing with various issues and the dynamics of social life.}

According to Koentjaraningrat (1987) consists of the cultural value conceptions of life in the minds of citizens largely on matters they consider very precious. Clyde Kluckhohn in Pelly (1994) defines the general conception of cultural values as an organized, affecting the behavior related to nature, the place of humanity in nature, the relationship with the people and about things that are desirable and undesirable.

Furthermore, the starting point of the above opinion, it can be said that every individual in carrying out its social activities are always guided by the values which exist and live in the community itself. This means that these values are very much influence the actions and behavior of human beings, individually, group or society as a whole about good or bad, right or wrong, improper or inappropriate. A value when they are entrenched in a person, then that value will be used as guidance or direction in the act.

One of the cultural values prevailing in South Sulawesi is Siri '. Siri' for Makassar people become a source of value and image of the community recognized and highly maintained so that the whole attitude, behavior, or words of Makassar people is measured by cultural values. Siri' is a system of values and norms serve as a reference and influence in interpreting and assessing something outside and inside ourselves, so that in all actions are always based on the values of siri'. Siri' in Makassar Bugis society is a guideline and basic capital in life (Salam, 2012). The values of Siri' can be one of social tools as transformation, motivations so that people in Kampung Nelayan Arungkeke can have the values of great social ethos in the act which is not always be the object.

The phenomenon of tradition that runs on society is a series of customs of the people in the village Arungkeke longstanding decorate behavior livelihoods for communities Kampung Nelayan Arungkeke. Tradition is far from the functions of culture itself, Suparlan (1988) explains, culture and development have links functional.

Patterns of behavior conducted by the fishing community, especially in organizing the party is quite a burden for society survival priorities. Remuneration system or a system restore time giving a party or celebration is a requirement, because it will be a social problem if not done in accordance systems prevailing in the community of Kampung Nelayan Arungkeke.

On the other hand the principle of fishermen is roughing, the principles do not reflect the culture of siri' a cultural value that serves as a dynamic factor in the improvement in the lives of fishermen. Culture of siri' is known in the community of Jeneponto something unusual for the fisherman community. Siri' does not have sacred values again so that the fishermen always have habits and patterns of behavior that leads him to powerlessness in the face of life. On the concept of culture has a very large function for humans and society.

On the concept of transformation of cultural values, then regardless of the view of Geertz (1973) suggested that culture is a system or arrangement of symbols and meanings that apply to the social interaction of a community, while Kluckhohn (1951) states that culture is the memory of the community.

Observing the cultural values of several approaches, there are three general cultural pattern linkage of cultural values which can be one of the cultural ethos of social footing as the act of Abu Hamid (2003), namely:

a. Guilt-culture; the cultural meaning of guilt (guilt-culture) when applied to fishermen communities, it can create a social ethos, that guilt as a driver, for the fulfillment of life in particular and the driver of development in 
general.

b. Shame-culture; the cultural meaning of shame (shame culture) for the fisherman community can serve as encouragement of achievement and foster creativity in the life of the fishermen community. Culture of shame that can be interpreted as Siri 'united as a culture of shame to spur success in development.

c. Culture of fear end (fearand-culture); meaning a culture of fear will end (fearand-culture) to foster thrift, careful, careful in action, and the nature of that support in the move in creating a better life.

Cultural meanings by referring to the concept of world view for the fishermen community, it would produce a work ethic and the work that can lead to the betterment of life in society and culture.

Of the three general cultural pattern that fit the concept of Abu Hamid (2003) can create the ethos and world view, it is better if placed on future orientation. With a world view can bring forth the design and strategy of the values of the custom as a means of social and cultural transformation.

The conceptual framework of Kluckhohn and Strodtbeck (1961) there are five principal issue in the Life, one of the cultural approach which serves as a social cultural transformation for fishermen communities of Arungkeke those are:

a) (MH), human nature, life was hard but humans must endeavor to live it to be good;

b) (MK), the work of man, works as a movement of life that should result in more work anymore.

c) (MW), the nature of time, is expected to have a view oriented as far as possible towards the future, life planning becomes an extremely important point.

d) (MA), the nature of the human relationship with the natural surroundings, is expected to man should always try to conquer nature, people trying to find harmony with nature.

e) (MM), the nature of man's relationship to his fellow man, is expected selfish individualism, the idea that man must be able to stand on its own.

Both cultural approach mentioned above, at least it can be a reference to the functioning of cultural values as the motor of cultural transformation in Kampung Nelayan Arungkeke. Kampung Nelayan Arungkeke as a fishing village that was once the village of modeling by the government to get out of the stagnation / poverty / involution fisheries.

\subsubsection{Social Transformation through work ethic.}

In communities of Kampung Nelayan Arungkeke actually have properties that enterprising, this can be seen by the time the fishing activities starting from the afternoon until the next morning. However, the fishing activity does not necessarily have social values or views that have the orientation to the future, that everything is well planned, both in terms of time, the conditions for the future to be better than yesterday.

The approach by Weber (1885) about the relationship with the Protestant ethic and the spirit of capitalism study McClelland (1961), about the achievement motive relationship with economic development to be the cause of cultural factor in economic development. The role of religion is a factor causing or encouraging the emergence of capitalism in Western Europe and the United States. The rapid economic progress with capitalism is the contribution or the main cause is often referred to as the Protestant Ethic. So it could be interpreted that arise and the rapid progress of Western economies is a form of religious or caused by the Protestant ethic at that time.

Likewise in the teachings of the religion of Islam as a religion professed by the fishing communities in Arungkeke can be used as a driving force for the betterment of life for the fishermen community. Clifford Greertz (1976), defines religion as a system of symbols that serves to "pacify the mood" and provide strong motivation in human life by setting concepts or formulate beliefs about the general order of existence (human society) and wrapping concepts or beliefs it as if it was something real or is the fact that the inner atmosphere and motivation that is created becomes real.

\subsubsection{Transformation of Social Values of Fishermen Community through Public Education}

Given the fishermen communities are communities that have special properties, then the model adopted is a fishermen's empowerment through education models based on community needs and the fishermen community. The concept of community-based education of fishermen basically refers to the concept based on the special needs of fishing communities, namely how to create a community on the fishermen community had a need for basic education for the children of fishermen. It is the paradigm of the fishermen community that education is not important.

Lack of education and skills is one of the factors of poverty in fishermen communities Arungkeke, the necessary skills-based on education pattern. The pattern of education formulated in this study, was more education to follow the social condition of the community itself. The fishermen communities need to be educated social values as a function of the driving force in need fulfillment activities, which by Paulo Freire (1972) referred to the public education as the 
transformation of social values.

Education models offered on the condition of this study was education more closely follow the social condition of the community itself. The fishermen communities need to get an education based on social values as a function of the driving force in fulfilling the needs of the fishermen community activities. The function of social values is the driving factor ideals or hopes for social life, a guidance way of thinking, feeling, acting, as well as guidance in weighing the public's assessment, unifying solidarity in the life of the group and a bastion of protection for the stability of the cultural group or community (Setiadi and Kolip, 2011).

\subsubsection{Build custom deliberation in Village, Building Social Transformation}

According to Hurst (2000) stated that the meeting between members of the public space is expected to create meeting members of village communities through initiation together to develop the capacity of community participatory mapping the problem. Mapping the social problems that occur in a family of fishermen, awareness will cause the condition of involution although the fishermen village was once a special attention from both central and local government. Consultation through the village, it is expected the creation of a process of social transformation for the community. The process of social transformation requires awareness of each individual in society. To be able to grow the awareness needed stimulation that gives direction to the fulfillment of basic needs. This is where the role of chaperone / character village consultation is indispensable as a facilitator, motivator and a dynamic system or foster father / mentor. The stimulus given to reduce the poverty rate (speed up the process of social transformation).

\section{Conclusion}

Perspective structural functionalism in sociology anthropology is essentially based on the concepts developed by Emile Durkheim. According to Durkheim (in Poloma, 1994) is an overall community of organisms that have a social reality. Overall it has a set of requirements or certain functions that must be met in order to exist in a state of normal and persist. To realize the structure and functions of the device needs to create the conditions stabilizers in a community, the community of Kampung Nelayan Arungkeke expected social transformation can occur social change culture and structure of fishing communities. Social transformations such as the presence of a work ethic, change of mindset, creative, dynamic and able to exploit the natural resources available in coastal areas. Of changes in mindset promote changes in the course of action, the influence of social, cultural and technology into coastal communities petrified acceleration of the social transformation.

\section{References}

Abu Hamid. (2003). Siri' dan Pesse, Harga Diri Orang Bugis, Makassar, Mandar, Toraja. Pustaka Refleksi.

BAPPEDA. Kerangka Pembangunan Strategi Kabupaten Daerah tingkat II Jeneponto, tahun 2007/2010, Badan Perencanaan Pembangunan Daerah (BAPPEDA), Kabupaten Daerah Tingkat II Jeneponto Tahun 2007.

Boeke JH. (1946). Oosterse Ekonomic. Den Haag N Service.

Chourmain, MAS, Imam. (2008). Acuan Normatif Penelitian Untuk Penulisan Skripsi, Tesis \& Disertasi. Jakarta: Al-Haramain Publishing House.

Geertz, Clifford. (1963). Aqricultural Involution: The Process of Ecological Change in Indonesia. California: University of California Press. Clifford Geertz. (1976). Agriculture Involution translated by S. Supomo, Involusi Pertanian. Jakarta: Bharata Karya.

Hurst WJ. (2000). Methods of Analysis for Functional Foods and Nutraceuticals. Florida: CRC Press.

Kaplan D. (2002). The Theory of Culture Teori Budaya. Yogyakarta: Pustaka Pelajar.

Koentjaraningrat. (1987). Sejarah Teori Antropologi I. Jakarta: UI-Press.

Kluckhohn, F.R. and F.L. Strodtbeck. (1961). Variations in Value Orientation: A Theory Tested in Five Cultures. Evanston, Illinois: Row, Peterson and Co.

Kluckhohn C. Kluckhohn. (1951). Value and Value Orientations in The Theory of Action. An Exploration in definition and clarification. Parson \& Edward Shils (ed) Harvard University Press.

McClelland. David C. (1961). The Achieving Society. USA: Van Nostrand.

Muhajir, Noeng. (1996). Metode Penelitian Kualitatif. Yogyakarta: Rakesarasin.

Paulo Freire. (1972) Pendidikan Kaum Tertindas. Jakarta:LP3S.

Pemda Kabupaten .Jeneponto. 2008. Rencana Pembangunan Jangka Menengah Daerah Kabupaten Jeneponto Tahun 2008-2013).

Poloma, Margaret M. (1994). Sosiologi Kontemporer, translated by team of Yasogama. Jakarta: Raja Grafindo.

Rahmat, Jalaluddin. (1987). Metode Penelitian Komunikasi. Bandung: Remaja Rosdakarya.

Salman. (2002). Tahap Transisi dalam Transformasi Industrial pada Komunitas Maritim di Sulawesi Selatan, Disertasi UNPAD. 
Sarono Kartodirdjo, Pendekatan IImu Sosial dalam Metodologi Sejarah, (Jakarta:Gremedia Pustaka Utama. 1993

Setiadi, Elly M dan Usman Kolip. 2011 .Pengantar Sosiologi Pemah aman Fakta dan Gejala Permasalahan Sosial. Teori, Aplikasi, dan Pemecahannya . Jakarta: Kencana.

Soedjatmoko. (1985). Pembangunan Sebagai Proses Belajar. XXXIV ed. Yogyakarta: Yayasan BP-Bazis.

Sugiyono, 2011, Memahami Penelitiab Kualitatif. Penerbit Alfabeta, Bandung.

Suyanto Bagong. (2008). Struktur Sosial. Pusat Pengembangan dan Pemberdayaan Pendidik dan Tenaga Kependidikan PKn dan IPS.

Suyanto, Bagong. (2013). Anatomi Kemiskinan dan Strategi Penanganannya. Malang: In-Trans Publishing Suyanto, Bagon

Suyanto, Bagong. (2008). Perangkap Kemiskinan dan Model Pemberdayaan Masyarakat Miskin dalam Mengurai Benang Kusut Masalah Kemiskinan di Indonesia. Jurnal DIALOG Kebijakan Publik, 3' ${ }^{\text {rd }}$ Ed, November, 2008.

Suparlan, Supardi. (1988). Kebudayaan Kemiskinan dalam Kemiskinan di Perkotaan: Bacaan Untuk Antropologi Perkotaan. Yogyakarta: YOI.

Siswanto B. (2008). Kemiskinan dan Perlawanan Kaum nelayan. Malang: Laksbang Mediatama, pp. 193-216.

Solihin Akhmad. (2010). Mencermati Involusi Nelayan Sumur, [online]. Vol.1.

Soemardjan. Selo. (1980). Jurnal Sosiologi Indonesia. Jakarta: Ikatan Sosiologi Indonesia.

Weber, Max. (1985). The Protestant Ethic and the Spirit of Capitalism (Conterpoint Ed). Sydney: Unwin Paperbacks. 